\title{
A Research of nasal methicillin resistant/sensitive Staphylococcus aureus and pharyngeal beta-haemolytic Streptococcus carriage in midwifery students in Kahramanmaras, Eastern Mediterranean Region of Turkey
}

\author{
Ekrem Kirecci ${ }^{1}$, Ali Ozer ${ }^{2}$, Murat $\mathrm{Aral}^{3}$, Meral Miraloglu ${ }^{1}$
}

\begin{abstract}
Background: In the hospitals where hygienic conditions are not provided, nasal methicillin resistant/sensitive Staphylococcus aureus (MRSA/MSSA) colonization is seen in the hospital personnel and patients. Both the individuals' themselves being MRSA/MSSA carriers and also other people around them are under risk and this bacterium leads to nasal colonization and then can propagate through contaminated hands and hospital materials.

Objective: In this study, it was aimed to research MRSA/MSSA and beta-haemolytic streptococcus (BHS) carriage in the nose and throat flora of students of, School of Health.

Methods: In the study, total of 160 midwifery students taking midwifery education was included in the research but $135(84.4 \%)$ out of 160 students were able to be reached. The nose and throat swab samples taken from students were examined through microbiological methods.

Results: $14.1 \%$ of students were nasal MSSA carrier. While there wasn't the nasal MRSA carrier among students attending the study in the 1 st and 2 nd class, $3.3 \%$ (1 person) of the 3 rd class students and $10.0 \%$ (3 people) of the 4 th class students were the nasal MRSA carrier. In addition, BHS carriage was determined in $1.5 \%$ of students and there wasn't any difference between classes.

Conclusions: These results indicate that midwifery students might have been contaminated with MSSA/MRSA during clinical practice. That MSSA/MRSA being an important pathogen is seen in midwifery students taking education in the birth units threatens the mother-child health. [Ethiop. J. Health Dev. 2010;24(1):57-60]
\end{abstract}

\section{Introduction \\ Staphylococcus aureus colonies are found in approximately $30 \%$ of the general population. In approximately one tenth of these ( 3 percent of the general population) there are methicillin resistant/sensitive S.aureus (MRSA/MSSA), and these people are known as people having MRSA colonization in their bodies (1). Especially in the hospitals where hygienic conditions are not provided, nasal MRSA colonization is seen in the hospital's personnel and patients (2). Both the individuals' themselves being MRSA carriers and also other people around them are under risk and this bacterium leads to nasal colonization. Further more it can propagate through contaminated hands and hospital materials $(3,4)$.}

Streptococci are bacterial disease factors which are not evaluated among nosocomial factors but commonly take place in the nature and are most often met especially in childhood with the throat infections (5). Pharyngeal carriage in asymptomatic people bears big importance in epidemiology of the A and B Group beta-haemolytic streptococcus (BHS) infections. Especially the Group B streptococci become colonized in pharynx and vagina flora and so can lead to many maternal and neonatal infections such as intra-amniotic infection, early membrane rupture, premature birth risk, postpartum endometriosis, bacteremia after cesarean, bacteriuria during and after pregnancy $(25-30 \%)(6,7)$.

It is significantly important that the bacteria stated above shouldn't be found in the body flora of individuals being served in health services like the mother and child care before, during and after the birth.

Many researches concerning MRSA carriage in the hospital personnel are conducted globally but studies towards midwifery students are not adequate. In our country, the midwifery students take the applied education in the hospital units concerning the birth, mother and baby health for 4 years by starting from the first class and also visit homes for baby health. When these students don't comply with hygienic rules in the hospital medium adequately, they can become colonized with various pathogen microorganisms and can propagate these bacteria to other health personnel and patients. So in the protection of the mother and child's health, the prevention of $S$. aureus and BHS carriage in health personnel and students taking health education bears big importance.

In this study it was aimed to research MRSA/MSSA and BHS carriage in the nose and throat flora of midwifery

\footnotetext{
${ }^{\top}$ School of Health, Kahramanmaras Sutcuimam University, 46050, Kahramanmaras, Turkey

${ }^{2}$ Faculty of Medicine, Department of Public Health, Kahramanmaras Sutcuimam University, Kahramanmaras, Turkey

${ }^{3}$ Faculty of Medicine, Department of Microbiology, Kahramanmaras Sutcuimam University, Kahramanmaras, Turkey
} 
students of School of Health, Kahramanmaras Sutcuimam University.

\section{Methods \\ Design and specimen collection}

This is is a descriptive study. A total of 160 midwifery students taking education in the 2008-2009 term in Kahramanmaras Sutcuimam University, School of Health, Department of Midwifery was taken into the scope of the research and any sampling was not made. $135(84,4 \%)$ out of 160 students were reached. These students were taking the applied birth knowledge lesson in the birthing rooms of the Women's Birth Hospital and Medicine Faculty. The nose flora of students was examined with respect to $\boldsymbol{M R S A} \boldsymbol{A} \boldsymbol{M S} \boldsymbol{A}$ and the throat flora with respect to BHS colonization. With this aim, the throat and nose swab was taken from the students not having clinical symptoms (pharyngitis, cryptic tonsillitis, sinusitis, otitis media, and other upper respiratory illnesses), and swabs of throats were sampled in early morning time and cultures were made. The throat swab samples were taken from tonsillaris and pharynx mucosa with dry, sterile swab and the nose swab samples were taken from the anterior nares of nose with the swab soaked with sterile serum physiologic. While taking samples, it was paid attention that there weren't findings such as fever, hyperemia, exudates, micro abscess bringing the infection thought into the mind in physical treatment and that there wasn't the use of the medicine like antibiotics.

\section{Isolation and identification of bacteria}

The throat and nose swab samples were arrived to the laboratory and planted to 5\% sheep blood agar and 7.5\% salt and mannitol (Chapman) culture and then incubated in the sterilizer of $37^{\circ} \mathrm{C}$. In these cultures, if there wasn't doubtful reproduction, colonies in the Gram positive coccus were identified microscopically according to their appearances in the beta-hemolysis, colony morphology and Gram stained preparate, and BHS, mannitole effect, coagulase, catalase and DNAase, positive colonies were identified as S.aureus. BHS strains were typed with the latex agglutination (Dryspot Streptococcal Grouping Kit, Oxoid) test $(8,9,10)$.

Methicillin susceptibility testing of staphylococcus strains

The methicillin susceptibility test was made with KirbyBauer disk diffusion method according to CLSI criteria.
A bacterium suspension in 0.5 McFarland turbidity standard was prepared from each S.aureus strain. The plantation was made to Mueller-Hinton agar from these suspensions and the oxacillin disk $(1 \mu \mathrm{g})$ was placed to the culture plates and the plates were incubated for 24 hours at $35^{\circ} \mathrm{C}$ in the aerop medium. Of colonies reproducing, those having $13 \mathrm{~mm}$ zone diameter were accepted as sensitive, those having 11-12 mm as medium sensitive and strains forming the inhibition zone under 11 $\mathrm{mm}$ as methicillin resistant. In the study, S.aureus ATCC 25923 strain was used for the control $(11,12)$.

\section{Statistical analysis}

Fisher's exact test was used in statistical analyses and $\mathrm{p}<0.05$ level was accepted as meaningful. The statistical analysis was performed using SPSS (SPSS 12.01 for windows SPSS Inc. 2003).

\section{Ethical approval}

The study was approved by the Ethics Committee at the Medical School of the University of Kahramanmaras Sutcuimam, and all subjects provided their oral informed consent before participating in the study.

\section{Results}

$30.4 \%$ of 135 midwifery students attending the research were in the $1^{\text {st }}$ class, $25.2 \%$ in the $2^{\text {nd }}, 22.2 \%$ in the $3^{\text {rd }}$ and $22.2 \%$ in the fourth. The total of 135 students evaluated in the scope of the study was attending actively to the applied lessons in the hospital medium. While there wasn't the nasal MRSA carrier among students attending the study in the $1^{\text {st }}$ and $2^{\text {nd }}$ class, $3.3 \%$ ( 1 person) of the $3^{\text {rd }}$ class students and $10.0 \%$ ( 3 people) of the $4^{\text {th }}$ class students were the nasal MRSA carrier. In the $4^{\text {th }}$ class students the MRSA carriage was meaningfully higher than other classes $(p<0.05)$ (Table 1$) .14 .1 \%$ of midwifery students were nasal MSSA carrier and this ratio was $4.9 \%$ in the $1^{\text {st }}$ class students, $8.8 \%$ in the $2^{\text {nd }}$ class and $23.3 \%$ in the $3^{\text {rd }}$ and $4^{\text {th }}$ classes. In the $3^{\text {rd }}$ and $4^{\text {th }}$ classes the nasal MSSA carriage was found out meaningfully higher than the $1^{\text {st }}$ and $2^{\text {nd }}$ classes $(\mathrm{p}<0.05)$ (Table 2). As seen in Table 3, while pharyngeal BHS carriage was negative in the $1^{\text {st }}$ and $3^{\text {rd }}$ classes, it was positive in $2.9 \%$ of the $2^{\text {nd }}$ classes and in $3.3 \%$ of the $4^{\text {th }}$ classes. The distribution of pharyngeal BHS carriage of midwifery students according to their classes was not meaningfully different $(\mathrm{p}<0.05)$ (Table 3$)$.

Table 1: Nasal MRSA carriage according to classes students study in Kahramanmaras, Turkey (2008-2009).

\begin{tabular}{lcccccc}
\hline \multirow{2}{*}{ Class } & \multicolumn{2}{c}{ Positive } & \multicolumn{2}{c}{ Negative } & \multicolumn{3}{c}{ Total } \\
\cline { 2 - 7 } & $\mathbf{N}$ & $\mathbf{N}$ & $\mathbf{N}$ & $\mathbf{N}$ & \multicolumn{1}{c}{} \\
\hline $1^{\text {st }}$ class & 0 & 0.0 & 41 & 100.0 & 41 & 100.0 \\
$2^{\text {nd }}$ class & 0 & 0.0 & 34 & 100.0 & 34 & 100.0 \\
$3^{\text {rd }}$ class & 1 & 3.3 & 29 & 96.7 & 30 & 100.0 \\
${ }^{\text {th }}{ }^{\text {class }}$ & 3 & 10.0 & 27 & 90.0 & 30 & 100.0 \\
\hline Total $(\mathbf{n})$ & 4 & 3.0 & 131 & 97.0 & 135 & 100.0 \\
\hline
\end{tabular}

* The difference is sourced from this group. $\chi^{2}=5.37, p=0.03$ 
Table 2: Nasal MSSA carriage according to classes students study in Kahramanmaras, Turkey (2008-2009).

\begin{tabular}{|c|c|c|c|c|c|c|}
\hline \multirow{2}{*}{ Class } & \multicolumn{2}{|c|}{ Positive } & \multicolumn{2}{|c|}{ Negative } & \multicolumn{2}{|c|}{ Total } \\
\hline & $\mathbf{N}$ & $\%$ & $\mathbf{N}$ & $\%$ & $\mathbf{N}$ & $\%$ \\
\hline $1^{\text {st }}$ class & 2 & 4.9 & 39 & 95.1 & 41 & 100.0 \\
\hline $2^{\text {nd }}$ class & 3 & 8.8 & 31 & 91.2 & 34 & 100.0 \\
\hline$* 3^{\text {rd }}$ class & 7 & 23.3 & 23 & 76.7 & 30 & 100.0 \\
\hline$* 4^{\text {th }}$ class & 7 & 23.3 & 23 & 76.7 & 30 & 100.0 \\
\hline Total (n) & 19 & 14.1 & 116 & 85.9 & 135 & 100.0 \\
\hline
\end{tabular}

Table 3: Pharyngeal BHS carriage according to classes students study in Kahramanmaras, Turkey (2008-2009).

\begin{tabular}{ccccccc}
\hline \multirow{2}{*}{ Class } & \multicolumn{2}{c}{ Positive } & \multicolumn{2}{c}{ Negative } & \multicolumn{2}{c}{ Total } \\
\cline { 2 - 7 } & $\mathbf{N}$ & $\mathbf{N}$ & $\mathbf{N}$ & $\mathbf{N}$ & \multicolumn{1}{c}{} \\
\hline $1^{\text {st }}$ class & 0 & 0.0 & 41 & 100.0 & 41 & 100.0 \\
$2^{\text {nd }}$ class & 1 & 2.9 & 33 & 97.1 & 34 & 100.0 \\
$3^{\text {rd }}$ class & 0 & 0.0 & 30 & 100.0 & 30 & 100.0 \\
$4^{\text {th }}$ class & 1 & 3.3 & 29 & 96.7 & 30 & 100.0 \\
\hline Total $(\mathbf{n})$ & 2 & 1.5 & 133 & 98.5 & 135 \\
\hline
\end{tabular}

\section{Discussion}

Methicillin-resistant Staphylococcus aureus (MRSA) is an important nosocomial pathogen. It can lead to epidemics and its antibacterial treatment options are limited (13). Infection was determined in $45 \%$ of patients lying in intensive care units of hospitals in European countries and it was detected that $21 \%$ of these were the MRSA acquired in the hospital (14). It is significantly important to examine MRSA infections epidemiologically since S.aureus gains multiple resistance against antibiotics and transforms into an endemic hospital factor, its eradication realizes hard and due to the fiscal load brought along by epidemic diseases. Numerous MRSA strains leading to epidemics were defined but it was determined that these strains did not always show propagation $(15,16)$. To treat and prevent the nasal MRSA carriage plays key role in epidemics of MRSA infections and in pathogenesis of the disease. Reva et al (2009) (17) investigate pathogen carriage in nursing students and determined that hand/nasal MSSA carriage increased (18.2\%) depending on clinical applications. MSSA carriage was similarly $14.1 \%$ in our study as well and this ratio was increasing in the upper classes. In the same study, while Reva et al (2009) (17) were not able to find MRSA in the hand/nasal flora of the students not taking clinical application, MRSA was determined $6.1 \%$ in the students making clinical practice in the hospital. 3.0\% of the students attending our study were nasal MRSA carriers and these students were in the $3^{\text {rd }}$ and $4^{\text {th }}$ classes. In the upper classes taking more applied lessons than the $1^{\text {st }}$ and $2^{\text {nd }}$ classes it was determined that the carriage meaningfully increased based on the increase in the work in the hospital medium.

The nasal MRSA carriage was investigated in Nebraska High School athletes between 2006-2008 years and the community acquired MRSA (CMRSA) was isolated in 51 out of 271 students (18). That MRSA carriage is seen in this ratio in healthy individuals not taking place in the hospital medium shows dimensions of the risk to be met with respect to the public health.

In our country preschool 0-6 age group children go to health centers due to various health problems at least 9 times until 1 years old, and after 1 years old one time in a year (14). In addition, midwifes visit homes for the mother-child health in certain periods. In a study made in our country, the nasal S.aureus carriage was investigated in 200 children being in the 0-6 age group and S.aureus colonization was detected in $18 \%$ of children. Also, methicillin resistance was determined in 5.6\% of these strains (13). In another study, the nasal S.aureus carriage was compared between two groups and the carriage ratio was found to be $32.4 \%$ (59.1\% for surgeons and $22.7 \%$ for other surgical staff) in the surgery clinic personnel taking place in the $1^{\text {st }}$ group and this ratio was found to be $21.6 \%$ in biology faculty students taking place in the $2^{\text {nd }}$ group. In the same study, when looked at the results taken from the hospital personnel, it was revealed that both nasal carriage and antibacterial resistance in the isolated bacteria were meaningfully high (19). Both our study's results and also other studies show that nasal S.aureus (MSSA/MRSA) is mostly acquired in the hospital medium and then propagates to the patient and near surrounding (19). In our study, when pharyngeal BHS carriage was also investigated in midwifery students, the Group A BHS carriage was available in $1.5 \%$ of students and there wasn't meaningful difference according to groups. This situation can be dependent on that BHS is not a pathogen acquired in the hospital medium and it is generally a community acquired factor. Since the A group leads to diseases such as hemolytic streptococci and streptococcal tonsillo-pharyngitis, it is very important especially for the child health. These bacteria can infect individuals in the places where the populations such as school, day nursery and hostel are intensive through aerogenic way (20). 
In our study BHS carriage was determined in very low ratio and not concerned with the hospital medium. However BHS existence being an important pathogen both in adults and children shouldn't be ignored.

In conclusion, when MRSA contaminates a hospital, its eradication becomes difficult. In the struggle with MRSA, microbiological scanning must be done to the infected or colonized patients, the carriers must be determined and treated. Personnel must be informed, the hands must be washed before and after the contact with the patient and a suitable antiseptic must be applied. Contaminated material must be disinfected or sterilized and the gloves and aprons must be used during the contact with the patient. Except some special situations like mucus aspiration, there isn't need for wearing mask. MRSA carriage must be determined and the control of responsible midwife or nurse must be in the entries to isolated patient rooms. The rules of being protected from the hospital infections and hygiene rules must be taught practically to the students taking midwifery, nursing or medicine education. That MRSA being one of the hospital infection factors is found especially in midwifery students interning in the birth units, visiting homes for the mother-child health and working especially in the birth units in their occupational lives threatens the mother-child health seriously. So for the mother-child health, the carriage of both MRSA/MSSA and other pathogens in midwifery students and personnel must be periodically investigated and identified and treated.

\section{Acknowledgements}

We are grateful to all the midwifery students who participated in this study.

\section{References}

1. Doebbeling BN. Nasal and hand carriage of Staphylococcus aureus in healthcare workers. J Chemother 1994;6:11.

2. Kluytmans J, Belkum AV, Verbrugh H. Nasal Carriage of Staphylococcus aureus: Epidemiology, Underlying Mechanisms, and Associated Risks. Clin Mic Rev 1997;10:505-20.

3. Mulligan ME, Murray-Leisure KA, Standiford HC. Methicillin-resistant Staphylococcus aureus: A consensus review of the microbiology, pathogenesis, and implications for prevention and management. Am J Med 1993;94:313-28.

4. Gül M, Çıragil P, Aral M. Kahramanmaraş sütçü imam üniversitesi tıp fakültesi hastane personelinde burun ve el Staphylococcus aureus taşıyıcılığı. ANKEM Derg 2004;18:36-39.

5. Hızel K, Emekdaş G, Coşguner M, Altanlar N, Akın A. Kreş ve ilkokul çocuklarında a grubu beta hemolitik streptokok taşıyıcılığı. T Klin J Pediatr 1997;7:158-60.

6. Stanford TS, Robert R, Michael AG. Streptococcal pharyngitis.Dennis LS, Edward LK (Editors). Streptococcal infections: Clinical aspects, microbiology and molecular pathogenesis. New York Oxford University Press; 2000. p.76-78.

7. Carol JB. Group B streptococci infections. Dennis LS, Edward LK (ed).Streptococcal infections: Clinical aspects, microbiology and molecular pathogenesis. New York Oxford University Press; 2000. p. 223-32.

8. Edwards SM, Baker CJ. Streptococcus agalactiae (Group B Streptococcus) Mandell,Douglas and Bennet's (Editors). Principles and Practice of Infectious Diseases. Group B Streptococcus. Philadelphia Churchill Livingstone; 2000. p. 215262.

9. Nawaz SK, Riaz S, Riaz S, Hasnain S. Screening for anti-methicillin resistant Staphylococcus aureus (MRSA) bacteriocin producing bacteria. Afr J Biotechnol 2009;8(3):365-68.

10. Bilgehan H. Klinik Mikrobiyolojik Tan1. İzmir, Barış Yayınları, 3.Basım, 2002:35-55.

11. Koneman EW, Allen SD, Janda WM, Schreckenberger PC, Winn WC. Color Atlas and Textbook of Diagnostic Microbiology, Philadelphia Lippincott-Raven Publishers; 1997. p. 539-66.

12. Clinical and Laboratory Standarts Institute. Performance Standarts for Antimicrobial Susceptibility Testing; Eighteenth Informational Supplement. CLSI document M100-S18 [ISBN 156238-653-0]. Pennsylvania Clinical and Laboratory Standarts Institute; 2008.

13. Artan OM, Baykan Z, Artan C. Nasal carriage of Staphylococcus aureus in healthy preschool children. Jpn J Infect Dis 2008;61:70-2.

14. Çetinkaya Y, Ünal S. Metisilin dirençli Staphylococcus aureus infeksiyonlar1: Epidemiyoloji ve Kontrol. Flora 1996: 1 Supp 3:3-16.

15. Cookson BD, Philips I. Epidemic methicillinresistant Staphylococcus aureus. J Antimicrob Chemother 1988;24:57- 65.

16. Solberg CO. Spread of Staphylococcus aureus in hospitals: causes and prevention. Scand J Infect Dis 2000;32(6):587-95.

17. Reva-Balcı A, Celeboglu A, Uslu H, Uyanık MH. An evaluation of the hand and nasal flora of Turkish nursing students after clinical practice. J Clin Nurs 2009;18(3):426-30.

18. Bryan F, Buss MPH, Shawn W, Mueller RN, Theis M, Keyser A. et al. Population-Based Estimates of Methicillin-Resistant Staphylococcus aureus (MRSA) Infections Among High School Athletes-Nebraska, 2006-2008. JOSN 2009;25(4):282-91.

19. Tewodros W, Gedebou M. Nasal carrier rates and antibiotic resistance of Staphylococcus aureus isolates from hospital and non-hospital populations, Addis Ababa. ASTMH 1984;78(3):314-18.

20. Weber DJ, Rutala WA, Denny FW. Management of healthcare workers with pharyngitis or suspected streptococcal infections. Infect Control Hosp Epidemiol 1996;17:753-61. 